\title{
Seroprevalence of brucellosis in sheep and goats in the Arabian Gulf region
}

\author{
M. Ebid ${ }^{1}$, A. El Mola ${ }^{2}$ and F. Salib ${ }^{2}$ (i) \\ 1. Department of Animal Care and Medicine, General Organization of Veterinary Service, Giza, Egypt; 2. Department of \\ Medicine and Infectious Diseases, Faculty of Veterinary Medicine, Cairo University, Egypt. \\ Corresponding author: M. Ebid, e-mail: hyhamdy@yahoo.com \\ Co-authors: AE: ellmollaamal@gmail.com, FS: fayez vetmed@hotmail.com \\ Received: 31-12-2019, Accepted: 27-05-2020, Published online: 06-08-2020
}

doi: www.doi.org/10.14202/vetworld.2020.1495-1509 How to cite this article: Ebid M, El Molla A, Salib F (2020) Seroprevalence of brucellosis in sheep and goats in the Arabian Gulf region, Veterinary World, 13(8): 1495-1509.

\begin{abstract}
Background and Aim: Brucellosis is a zoonosis that occurs worldwide. There were more efforts to control brucellosis in all countries. This study was performed to determine the seroprevalence of brucellosis in sheep and goats in some areas in the Arabian Gulf.

Materials and Methods: The study analyzed 8500 sera from non-vaccinated sheep and goats. Animals included 6441 sheep (3420 from farms and 3021 from quarantine) and 2059 goats (1580 from farms and 479 from quarantine). Sera were tested using the Rose Bengal Plate Test (RBPT) and confirmed with an indirect enzyme-linked immunosorbent assay (i-ELISA) test. Final confirmation analyzed blood samples from confirmed infected animals $(n=30,23$ sheep and seven goats) using polymerase chain reaction (PCR) and culture.

Results: The serological examination showed that $62 / 8500$ of animals $(0.729 \%$, confidence interval [CI] 95\% $0.57-0.94)$ were seropositive for brucellosis. Thirteen of 5000 (0.26\%, CI 95\% 0.15-0.45) and 49/3500 (1.4\%, CI 95\% 1.1-1.8) of animals from farms and quarantine were seropositive, respectively. Out of the 6441, $46(0.71 \%)$ sheep and $16 / 2059(0.78 \%)$ goats were seropositive. i-ELISA confirmed 41/62 RBPT-positive animals - 41/8500 (0.482\%, CI 95\% 0.36-0.65). Eight of 5000 of these animals $(0.16 \%$, CI $95 \% 0.08-0.32)$ and 33/3500 $(0.94 \%$, CI 95\% $0.67-1.3)$ were confirmed positive in farms and quarantine, respectively. Thirty of $6441(0.466 \%)$ and $11 / 2059(0.534 \%)$ cases were positive in sheep and goats, respectively. PCR confirmed 18 of 41 positive animals $(0.212 \%$ of all sera, CI $95 \% 0.13-0.34)$ identified by both RBPT and i-ELISA. Three of $5000(0.06 \%$, CI $95 \% 0.019-0.19)$ and $15 / 3500(0.429 \%$, CI 95\% 0.26-0.71) from farms and quarantine were confirmed positive. Tissue samples (uterine, supra-mammary, testicular, and accessory glands lymph node) were collected from positive animals, as detected by RBPT and i-ELISA, at culling or slaughtering. Using in vitro culture, 14/30 were confirmed positive $-3 / 7$ from farms (two sheep and one goat) and 11/23 from quarantine (nine sheep and two goats). Biovar 1 was dominant. PCR confirmed 23/30 tissue samples, 4/7 from farms (three sheep and one goat), and 19/23 from quarantine (15 sheep and four goats).
\end{abstract}

Conclusion: The overall brucellosis rate in sheep and goats is $0.48 \%$, with fewer animals from farms testing positive $(0.16 \%)$ in this area of the Arabian Gulf. The infection appears to be well controlled, and continuous effort is still needed to maintain control and completely eradicate brucellosis. Additional support is needed for testing and slaughterhouse monitoring. In quarantine (imported animals), brucellosis infection in the slaughterhouse (0.94\%) could pose a risk for transmission and spread of infection. The effort is needed to monitor this threat, and PCR is a sensitive and time-saving test for brucellosis diagnosis. All 14 confirmed positive samples were Biovar 1 dominant.

Keywords: Arabian gulf, Brucellosis, goats, indirect enzyme-linked immunosorbent assay, polymerase chain reaction, Rose Bengal, seroprevalence, sheep.

\section{Introduction}

Brucella melitensis, in particular, is a reemerging pathogen in the Mediterranean, Arabian Gulf, and Middle East regions. The pathogen causes severe disease in livestock and has an enormous impact on the economy of developing countries [1]. Infection of sheep and goats causes abortions, weak offspring, reduced milk production, weight loss, infertility, and

Copyright: Ebid, et al. Open Access. This article is distributed under the terms of the Creative Commons Attribution 4.0 International License (http://creativecommons.org/licenses/by/4.0/), which permits unrestricted use, distribution, and reproduction in any medium, provided you give appropriate credit to the original author(s) and the source, provide a link to the Creative Commons license, and indicate if changes were made. The Creative Commons Public Domain Dedication waiver (http://creativecommons.org/ publicdomain/zero/1.0/) applies to the data made available in this article, unless otherwise stated. lameness. The disease has been eradicated in some countries, though the cost of surveillance to maintain a $B$. melitensis-free state remains high. The pathogen displays three Biovars (1, 2, and 3). Brucellosis is a common disease and an important zoonosis in the Mediterranean area. Continuous progress is notable for brucellosis control, yet it is still a significant public health hazard and of great economic importance [2-4]. Various methods of control have been adopted in different countries based on the elimination of infected animals detected by serological and other diagnostic tests, other control methods based on vaccination [5]. One of the most common zoonotic diseases has economic importance worldwide and has significant public health is Brucellosis [6,7]. Brucellosis is caused by a Gram-negative bacterium in the genus Brucella. 
These bacteria are facultatively anaerobic, non-motile, and intracellular coccobacilli. Brucellosis affects a wide range of mammals, including man, sheep, camels, cattle, goats, swine, and wildlife [1,8-10].

All three biovars cause disease in small ruminants, but their geographic distribution varies. Biovar 1 is most common in Libya and Oman, and Biovar 2 is dominant in Turkey and Saudi Arabia. Biovar 3 is most commonly encountered in Egypt, Jordan, and Tunisia. Saudi Arabia, Iran, the Palestinian Authority, Syria, Jordan, and Oman show the highest incidence rates for human brucellosis. Bahrain is reported as free of $B$. melitensis $[11,12]$ Typically, Rose Bengal Plate Test (RBPT) is used for field screening for brucellosis, sometimes along with indirect enzyme-linked immunosorbent assay (i-ELISA) [12-16]. Better approaches used more than one serological test, accompanied by molecular detection and culture, for the best diagnosis and control $[11,17]$. Nucleic acid amplification methods, such as polymerase chain reaction (PCR), are rapid, sensitive, and highly specific and can counteract limitations of conventional detection methods $[18,19]$. Furthermore, some bacterial infections, such as Chlamydia abortus, interfere with brucellosis in small ruminants [20]. A new PCR method shows high specificity and sensitivity for brucellosis diagnosis $[21,22]$. The technique can also be used to detect brucellosis in milk and milk products [23,24].

This study was conceived to address the lack of studies on the prevalence of brucellosis in sheep and goats in the gulf area and to update data on infection rate. Especially, the study aims to assess a wide range of incidence previously reported and to evaluate control methods, reporting by local authorities, and veterinary resources. The present study focused specifically on seroprevalence of brucellosis in sheep and goats in some areas surrounding the Arabian Gulf.

\section{Materials and Methods}

\section{Ethical approval}

This study was approved by the Research Ethics Committee at Cairo University. All samples, including blood samples and tissue samples, were collected following standard procedures without any animal harm with the acceptance of owners and local veterinary authority in Gulf Cooperation Council area.

\section{Study area and study period}

The study was performed in the Arabian Gulf region, characterized by a desert climate-scorching in summer and mild in winter. Only two main seasons exist; a hot period from April to October and a cooler period from December to February. Within the hot season, extreme heat extends from May to mid-October. March and November are intermediate warm months [25]. The present cross-sectional study was conducted between September 2014 and May 2018 with sheep and goat from farms, quarantine, and abattoirs in the Arabian Gulf region.

\section{Study population}

The study involved 85,000 non-vaccinated small ruminants and 855 farms represented by 8500 animals. The samples were collected animals from unorganized farms in four territories plus quarantine and eight organized farms. In selected localities, smaller administrative units or farms, as well as sheep flocks, and individual animals, were randomly selected and sampled using a simple random method [26].

Test animals included 6441 sheep and 2059 goats. Group 1 includes Four thousand animals from 252 unorganized farms in four territories, and 1000 animals from eight organized farms, (3420 sheep and 1580 goats). Group 2 includes 3500 animals from quarantine after import from different regions and countries (3021 sheep and 479 goats). The random animal selection was applied for farms and for the animals at farms. However, when farms noted gynecological problems, the samples were collected from both sick and healthy animals - full information about each animal-breed, sex, vaccination, and pathogenic condition

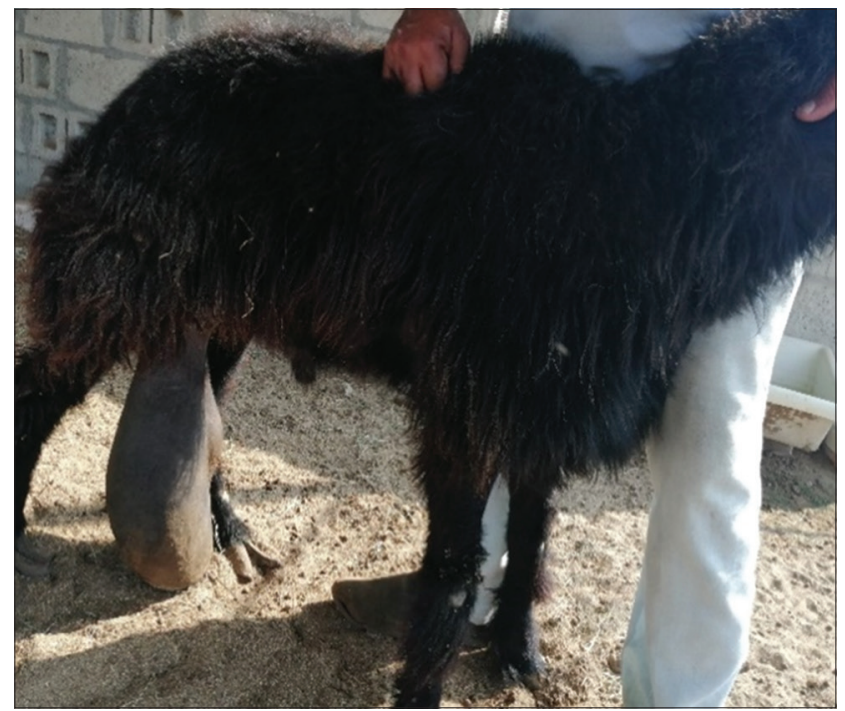

Figure-1: Unilateral orchitis in ram.

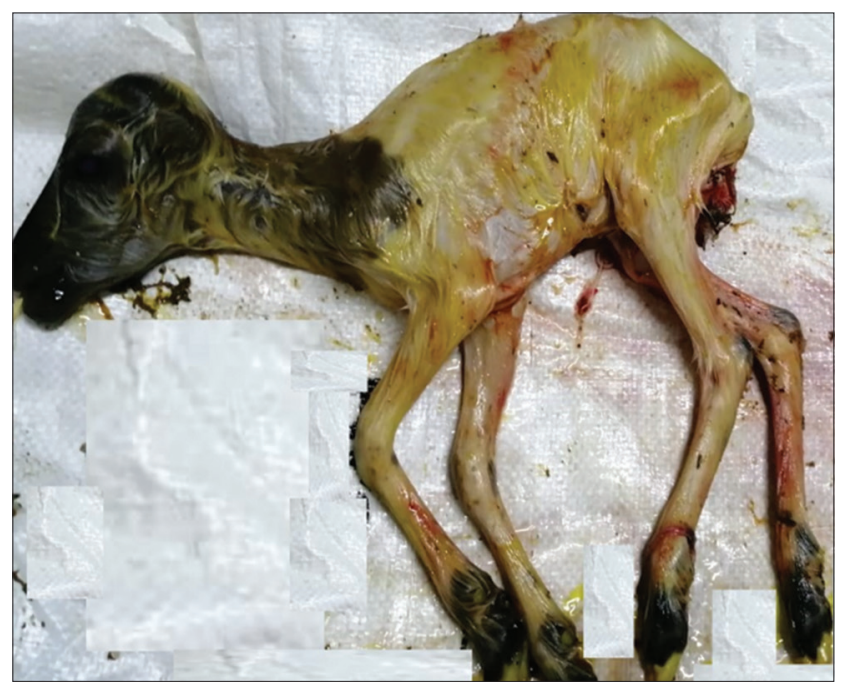

Figure-2: Aborted fetus of sheep. 
was recorded. Images of animal conditions, including orchitis, abortion, mastitis, endometritis, and retained placenta, were taken. Figures- 1 and 2 are examples of pathological conditions observed in the field.

\section{Sample size}

The sample size (n) needed to assess the prevalence of brucellosis, 8500 , was calculated using a standard formula [26,27]. The sample distribution between localities was $41.2 \%(n=3500)$, samples were from quarantine, $47 \%(n=4000)$ from unorganized farms, and $11.8 \%(\mathrm{n}=1000)$ from organized farms. Animals were selected from unorganized farms in four territories, the Northern Territory, 17.6\% $(n=1500)$, Southern, 14.1\% $(n=1200)$, Moharaq, 2.4\% $(n=200)$, and Middle, $12.9 \%(\mathrm{n}=1100)$. Data are summarized in Table-1. The sample size calculation used a confidence level of $95 \%$ and an error margin of $1 \%$.

\section{Sample collection \\ Blood samples}

Whole blood was collected from the jugular vein of each animal using two sterile Vacutainer tubes $(10 \mathrm{ml}$ of each). One tube without anticoagulant was used for serological tests, and the second tube with anticoagulant (EDTA) was labeled with codes describing animal and herd data recorded on investigation forms. Blood samples were kept in an upright position for $30 \mathrm{~min}$ in a cool place and then centrifuged at $3000 \mathrm{rpm}$ for $20 \mathrm{~min}$. The serum was collected by a micropipette and placed in Eppendorf tubes. Serum samples and blood samples were kept at $-20^{\circ} \mathrm{C}$ until used, as recommended by OIE [28]. Blood samples (Table-2) were collected for analysis by RBPT, i-ELISA, and PCR.

\section{Tissue samples}

Tissue specimens from Brucella seropositive animals after slaughter were collected for bacteriological and PCR examination. Tissue samples included uterus, uterine, and supra-mammary lymph nodes in females, testis, testicular lymph nodes, ampules, and epididymis, including surround fat. Some lymph nodes, especially retropharyngeal nodes, were also collected. Tissues were packed as resected in disposable packaging, transferred hygienically to the laboratory, and kept frozen at $-20^{\circ} \mathrm{C}$ till cultured and tested, as recommended by OIE [28]. All samples collected from one animal considered as one sample. Tissues were collected from 30 animals (Table-3) for examined by bacterial culture and PCR.

\section{Serological analysis of samples $R B P T$}

Serum samples were tested using the RBPT antigen, according to Alton et al. [29]. Briefly, $30 \mu \mathrm{L}$ of serum and $30 \mu \mathrm{L}$ of RBT antigen combined on the white ceramic plate and carefully mixed. The plate was agitated for $4 \mathrm{~min}$, and the degree of agglutination was recorded as a grade from $0,+,++$, and $+++[29]$. Grade $(0)$ indicates the absence of agglutination, grade $(+)$ indicate barely visible agglutination, grade $(++)$ indicates

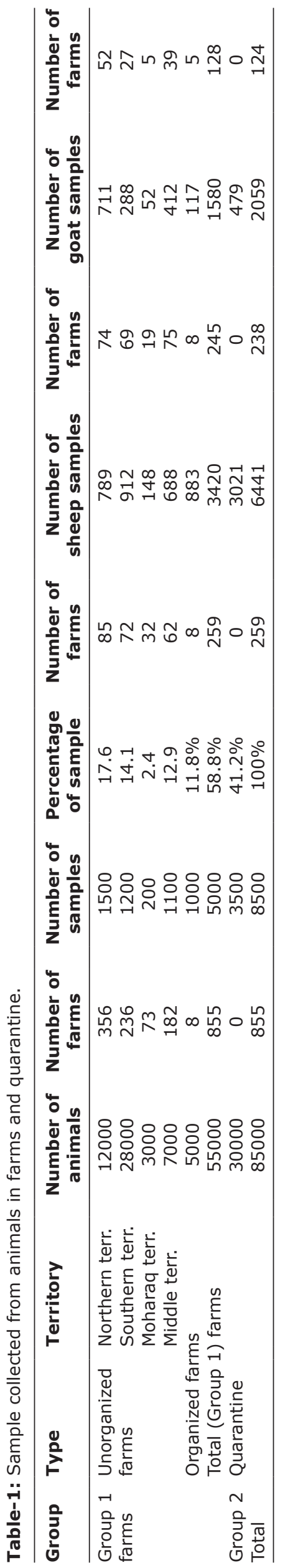

Veterinary World, EISSN: 2231-0916 
Table-2: Blood sample collected from animals.

\begin{tabular}{lllcccccc}
\hline Group & Type & Territory & $\begin{array}{c}\text { Number of } \\
\text { samples }\end{array}$ & $\begin{array}{c}\text { Number of } \\
\text { farms }\end{array}$ & $\begin{array}{c}\text { Number of } \\
\text { sheep samples }\end{array}$ & $\begin{array}{c}\text { Number } \\
\text { of farms }\end{array}$ & $\begin{array}{c}\text { Number of } \\
\text { goat samples }\end{array}$ & $\begin{array}{c}\text { Number } \\
\text { of farms }\end{array}$ \\
\hline Group 1 & Unorganized & Northern terr. & 1500 & 85 & 789 & 74 & 711 & 52 \\
farms & farms & Southern terr. & 1200 & 72 & 912 & 69 & 288 & 27 \\
& & Moharaq terr. & 200 & 32 & 148 & 19 & 52 & 5 \\
& & Middle terr. & 1100 & 62 & 688 & 75 & 412 & 39 \\
& Organized farms & 1000 & 8 & 883 & 8 & 117 & 5 \\
Group 2 & Qutal (Group 1) farms & 5000 & 259 & 3420 & 245 & 1580 & 128 \\
Total & Quarantine & 3500 & 0 & 3021 & 0 & 479 & 0 \\
\hline
\end{tabular}

Table-3: Tissue samples collected from confirmed positive reactors.

\begin{tabular}{|c|c|c|c|c|c|c|c|c|c|}
\hline \multirow[t]{2}{*}{ Group } & \multirow[t]{2}{*}{ Type } & \multirow[t]{2}{*}{ Territory } & \multirow[t]{2}{*}{ Total } & \multicolumn{3}{|c|}{ Sheep tissue sample } & \multicolumn{3}{|c|}{ Goats tissue sample } \\
\hline & & & & Sheep & $\begin{array}{c}\text { Number of } \\
\text { samples }\end{array}$ & $\begin{array}{l}\text { Sample } \\
\text { collected }\end{array}$ & Goats & $\begin{array}{l}\text { Number of } \\
\text { samples }\end{array}$ & $\begin{array}{l}\text { Sample } \\
\text { collected }\end{array}$ \\
\hline \multirow[t]{5}{*}{$\begin{array}{l}\text { Group } \\
1\end{array}$} & \multirow[t]{4}{*}{$\begin{array}{l}\text { Unorganized } \\
\text { farms }\end{array}$} & $\begin{array}{l}\text { Northern } \\
\text { terr. }\end{array}$ & 2 & 1 & 1 & $\begin{array}{l}\text { Uterus, ovaries, } \\
\text { and lymph nodes }\end{array}$ & 1 & 1 & $\begin{array}{l}\text { Uterus, ovaries } \\
\text { and lymph nodes }\end{array}$ \\
\hline & & $\begin{array}{l}\text { Southern } \\
\text { terr. }\end{array}$ & 2 & 2 & 2 & $\begin{array}{l}\text { Uterus, ovaries, } \\
\text { and lymph nodes }\end{array}$ & 0 & 0 & 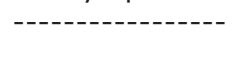 \\
\hline & & $\begin{array}{l}\text { Moharaq } \\
\text { terr. }\end{array}$ & 0 & 0 & 0 & - & 0 & 0 & ------------------ \\
\hline & & Middle terr. & 2 & 1 & 1 & $\begin{array}{l}\text { Uterus, ovaries, } \\
\text { and lymph nodes }\end{array}$ & 1 & 1 & $\begin{array}{l}\text { Uterus, ovaries } \\
\text { and lymph nodes }\end{array}$ \\
\hline & \multicolumn{2}{|c|}{ Organized farms } & 1 & 1 & 1 & $\begin{array}{l}\text { Uterus, ovaries, } \\
\text { and lymph nodes }\end{array}$ & 0 & 0 & -- \\
\hline \multirow[t]{3}{*}{$\begin{array}{l}\text { Group } \\
2\end{array}$} & \multirow{3}{*}{\multicolumn{2}{|c|}{ Quarantine }} & 23 & 18 & 1 & $\begin{array}{l}\text { Uterus, ovaries, } \\
\text { and lymph nodes }\end{array}$ & 5 & 2 & \multirow{4}{*}{$\begin{array}{l}\text { Testis and its } \\
\text { accessory glands } \\
\text { and lymph node } \\
\text { Accessory glands } \\
\text { and lymph node } \\
\text { (castrated male) }\end{array}$} \\
\hline & & & & & 7 & $\begin{array}{l}\text { Testis and its } \\
\text { accessory glands } \\
\text { and lymph node }\end{array}$ & & 3 & \\
\hline & & & & & 10 & $\begin{array}{l}\text { Accessory glands } \\
\text { and lymph node } \\
\text { (castrated male) }\end{array}$ & & & \\
\hline Total & & & 30 & 23 & 23 & & 7 & 7 & \\
\hline
\end{tabular}

finely dispersed agglutination, and grade $(+++)$ indicates coarse clumping. The samples with grade $(+,++$, and +++ ) were considered positive. Positive and negative control sera for comparison of the results were used.

\section{i-ELISA}

All samples that tested positive by RBPT were further analyzed by i-ELISA for confirmation. i-ELISA was performed following ELISA kit manufacturer's instructions "(ID. vet, ID screen, Brucellosis serum indirect multispecies, rue Louis Pasteur-Grabels - France)."

\section{$P C R$}

All positive samples that tested positive in both RBPT and i-ELISA assays were further tested by PCR.

DNA isolation used a DNA Purification Kit (Promega, USA) according to the manufacturer's instructions. Briefly, $300 \mu \mathrm{L}$ of the blood sample was placed in a sterile Eppendorf tube $(1.5 \mathrm{~mL}$ size $)$ and $900 \mu \mathrm{L}$ of erythrocyte lysis solution as added. The mixture was incubated for $10 \mathrm{~min}$ at room temperature $\left(22-25^{\circ} \mathrm{C}\right)$, and then centrifuged using a refrigerated Eppendorf centrifuge at 16,000 rpm for $1 \mathrm{~min}$. The leukocyte pellet was dispersed by vortexing for $20 \mathrm{~s}$ at high speed after discarding the supernatant. Three hundred microliter of nucleic lysis solution was added to the resuspended white pellet and pipetted for 3-5 times to lyse the white blood cells. The suspension was then incubated at $37^{\circ} \mathrm{C}$ for $1 \mathrm{~h}$, and $1.5 \mu \mathrm{L}$ of RNase solution was added by micropipette. Incubation was continued for 15-20 min and then a $100 \mu \mathrm{L}$ aliquot vortexed for $20 \mathrm{~s}$ at high speed. A small clump of protein was visible. After $4 \mathrm{~min}$ at room temperature, the lysate was centrifuged at $16,000 \mathrm{rpm}$. A dark brown protein pellet after centrifugation was visible. The supernatant containing total DNA was transferred to a clean $1.5 \mathrm{~mL}$ Eppendorf tube containing $300 \mu \mathrm{L}$ isopropanol at room temperature. The solution was gently mixed 5-8 times by inversion until white thread-like strands of DNA formed a visible mass. The samples were then centrifuged at $16000 \mathrm{rpm}$ for $5 \mathrm{~min}$ to recover DNA. DNA pellet was washed with $300 \mu \mathrm{L}$ of $70 \%$ ethanol, dried, and resuspended in $60 \mu \mathrm{L}$ of DNA rehydration solution. Extracted DNA was kept at $-20^{\circ} \mathrm{C}$ until use in PCR analyses. Concentration and purity of DNA were confirmed spectrophotometrically. Furthermore, agarose gels with $5 \mu \mathrm{L}$ of DNA were used to examine the quality and quantity of DNA. Finally, sheep glyceraldehyde 3-phosphate dehydrogenase was also used to confirm the quality of extracted DNA [30]. 


\section{Extraction of DNA from tissues}

Briefly, $3 \mathrm{~mL}$ of $1 \times$ phosphate-buffered saline and $1 \mathrm{~g}$ of a pooled sample of tissues (uterus, testes, accessory organ, and lymph node) were added to a $10 \mathrm{~mL}$ tube and tissue homogenized with a tissue homogenizer. After homogenization, the suspension was centrifuged at $3000 \mathrm{rpm}$ for $5 \mathrm{~min}$ at $4^{\circ} \mathrm{C}$. Two hundred microliter of supernatants and $600 \mu \mathrm{L}$ of nucleic lysis solution were mixed and pipetted repeatedly until no clumps of the cell were visible. The lysate was then incubated at $65^{\circ} \mathrm{C}$ for $15-30 \mathrm{~min}$ in a water bath. Three microliter of RNase was added and incubation was continued at $37^{\circ} \mathrm{C}$ for $15-30 \mathrm{~min}$. After cooling, DNA was obtained as described above.

\section{Primers}

Primer pairs specific to the IS711 element of $B$. melitensis, 5'AAATCGCGTCCTTGCTGGTCTGA3' and 5'TGCCGATCACTTAAGGGCCTTCAT3', were used to confirm $B$. melitensis in tissue and blood samples. The amplified product of this primer set was 731-bp identified with agarose gel electrophoresis [30] (Figure-3).

PCR

PCR amplification was performed using a Promega Go Taq Green Master Mix (USA). Briefly, the PCR mix included 12.5 $\mu \mathrm{L}$ of Go Taq Green Master Mix, $4.5 \mu \mathrm{L}$ nuclease-free water, $2 \mu \mathrm{L} \mathrm{MgCl}_{2}, 2 \mu \mathrm{L}$ of every forward and reverse primers, and $2 \mu \mathrm{L}$ of genomic DNA. A total volume of $25 \mu \mathrm{L}$ after that was initially incubated at $94^{\circ} \mathrm{C}$ for $4 \mathrm{~min}$. PCR was then performed with 35 cycles with $1 \mathrm{~min}$ for DNA denaturation at $94^{\circ} \mathrm{C}, 1 \mathrm{~min}$ at $50^{\circ} \mathrm{C}$ for primer annealing for the OMP 2 primers set, and $56^{\circ} \mathrm{C}$ for the $B$. melitensis specific primer set, and for polymerase-mediated primer extension at $72^{\circ} \mathrm{C}$ for $1.5 \mathrm{~min}$. The last (45) cycle included sample incubation for $10 \mathrm{~min}$ at $72^{\circ} \mathrm{C}$ and the retained at $4^{\circ} \mathrm{C}$ for an unlimited time. Seven microliters of the amplified product were analyzed by electrophoresis in $1.5 \%$ agarose gels in TBE buffer with ethidium bromide. DNA bands were visualized under UV light and photographed using an AlphaImager (Alpha Innotech) image documentation system [30].

\section{Identification of Brucella species from Brucella isolates}

Presumptive identification of $B$. melitensis was made based by observing small Gram-negative

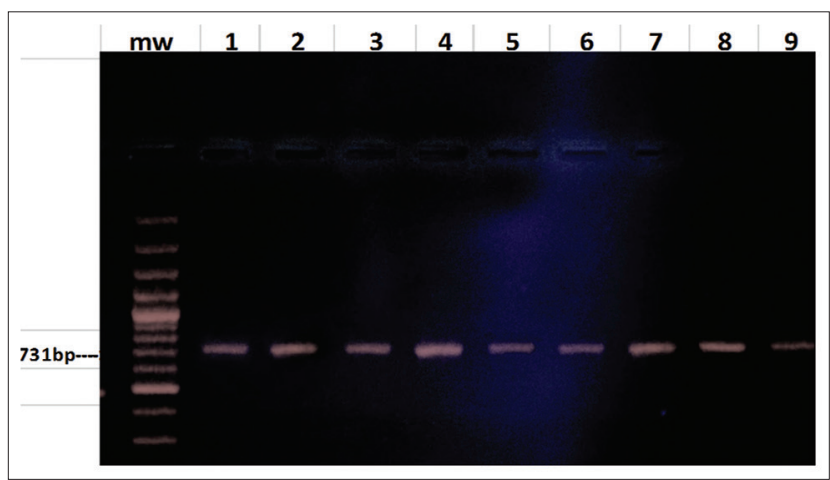

Figure-3: Polymerase chain reaction result in agar gel. coccobacilli, and biochemical tests positive for "oxidase, catalase, and urease," and further confirmed by antigen-antibody reaction agglutination with specific antisera (Remel Europe Ltd.). Moreover, identification, using Vitek 2 systems (version 07.01, BioMerieux), was performed with a Gram-negative bacteria colorimetric identification card (GN card) that contains different biochemical tests recommended by FAO/WHO expert committee on brucellosis [5,30].

\section{Statistical analysis}

Statistical analyses used the Statistical Package for the Social Sciences (SPSS) for Windows ${ }^{\circledR}$ version 20.0 (SPSS Inc., Chicago, Illinois). Descriptive statistics of the variables included frequencies and prevalence.

Variables of category - Brucella species, territory, farm, and animal sex - were expressed in numbers and percentages. The prevalence proportion was calculated as the number of animals testing positive by RBPT, i-ELISA, or PCR, divided by the total number of animals. Correlation among factors and outcome variables were assessed using Chi-square tests. For all analyses, $\mathrm{p}<0.05$ was considered significant.

\section{Results}

\section{Blood test}

$R B P T$

RBPT showed that $62 / 8500$ of animals $(0.729 \%$, confidence interval [CI] 95\% 0.57-0.94) were seropositive. Thirteen of $5000(0.26 \%$, CI $95 \% 0.15-0.45)$ and $49 / 3500(1.4 \%$, CI 95\% 1.1-1.8) animals were positive in farms and quarantine, respectively. Forty-six of 6441 sheep $(0.71 \%$, CI 95\% 0.54-0.95) were seropositive with $10 / 3420(0.292 \%$, CI 95\% $0.16-0.54)$ and $36 / 3021$ (1.192\%, CI 95\% 0.86-1.65) animals from farms and quarantine, respectively. Sixteen of 2059 goats $(0.78 \%$, CI $95 \% 0.48-1.27)$ were seropositive with $3 / 1580(0.19 \%$, CI $95 \% 0.06-0.59)$ and $13 / 479$ (2.7\%, CI 95\% 1.6-4.6) animals farms and quarantine, respectively (Tables-4 and 5).

\section{ELISA}

i-ELISA confirmed 41 of 62 RBPT-positive results, $0.482 \%$ of 8500 animals (CI 95\% 0.36-0.65). Eight of $5000(0.16 \%$, CI 95\% 0.08-0.32) and 33/3500 (0.94\%, CI $95 \% 0.67-1.3)$ were confirmed positive in animals from farms and quarantine, respectively. In sheep, 30 of $6441(0.466 \%$, CI 95\% $0.33-0.67)$ were positive. Of which 5/4320 (0.146\%, CI 95\% 0.06-0.35) and 25/3021 (0.828\%, CI 95\% 0.56-1.2) from farms and quarantine, respectively. Similar results for goats were 11/2059 (0.534\%, CI 95\% 0.3-0.96) total, 3/1580 (0.192\%, CI $95 \%$ 0.06-0.59) for farms, and 8/479 (1.68\%, CI 95\% 0.84-3.32) for quarantine (Tables-6 and 7).

\section{Territory distribution}

For Group 1 (farms), 13/5000 (0.26\%) animals were seropositive. The prevalence was $0.33 \%, 0.25 \%, 0 \%, 0.18 \%$, and $0.3 \%$ for Northern, 
Table-4: RBPT test result.

\begin{tabular}{|c|c|c|c|c|c|c|c|c|}
\hline \multirow[t]{2}{*}{ Group } & \multirow[t]{2}{*}{ Type } & \multirow[t]{2}{*}{ Territory } & \multicolumn{6}{|c|}{ RBPT results } \\
\hline & & & Total & $\%$ & Sheep & $\%$ & Goats & $\%$ \\
\hline \multirow[t]{6}{*}{ Group 1} & Unorganized farms & Northern terr. & 5 & 0.33 & 3 & 0.38 & 2 & 0.28 \\
\hline & & Southern terr. & 3 & 0.25 & 3 & 0.33 & 0 & 0.00 \\
\hline & & Moharaq terr. & 0 & 0.00 & 0 & 0.00 & 0 & 0.00 \\
\hline & & Middle terr. & 2 & 0.18 & 1 & 0.15 & 1 & 0.24 \\
\hline & Organized farms & & 3 & 0.30 & 3 & 0.34 & 0 & 0.00 \\
\hline & Total (Group 1) farms & & 13 & 0.26 & 10 & 0.29 & 3 & 0.19 \\
\hline Group 2 & Quarantine & & 49 & 1.40 & 36 & 1.19 & 13 & 2.71 \\
\hline Total & & & 62 & 0.73 & 46 & 0.71 & 16 & 0.78 \\
\hline
\end{tabular}

RBPT=Rose Bengal plate test

Table-5: RBPT result CI 95\%.

\begin{tabular}{|c|c|c|c|}
\hline & $\begin{array}{l}\text { Group } 1 \\
\text { farms }\end{array}$ & $\begin{array}{c}\text { Group } 2 \\
\text { quarantine }\end{array}$ & Total \\
\hline $\begin{array}{l}\text { Number of positive } \\
\text { RBPT }\end{array}$ & $13 / 5000$ & $49 / 3500$ & $62 / 8500$ \\
\hline$\%$ & 0.26 & 1.4 & 0.73 \\
\hline CI 95 & $0.15-0.45$ & $1.1-1.8$ & $0.57-0.94$ \\
\hline $\begin{array}{l}\text { Number of positive } \\
\text { RBPT sheep }\end{array}$ & $10 / 3420$ & $36 / 3021$ & $46 / 6441$ \\
\hline$\%$ & 0.29 & 1.19 & 0.71 \\
\hline CI 95 & $0.16-0.54$ & $0.86-1.65$ & $0.54-0.95$ \\
\hline $\begin{array}{l}\text { Number of positive } \\
\text { RBPT goats }\end{array}$ & $3 / 1580$ & $13 / 479$ & $16 / 2059$ \\
\hline$\%$ & 0.19 & 2.71 & 0.78 \\
\hline CI 95 & $0.06-0.59$ & $1.6-4.6$ & $0.48-1.27$ \\
\hline
\end{tabular}

$\mathrm{CI}=$ Confidence interval, $\mathrm{RBPT}=$ Rose Bengal plate test

Southern, Moharaq, Middle, and organized farms, respectively. Positive results confirmed that i-ELISA was obtained for $8 / 5000(0.16 \%)$ animals. The prevalence was $0.2 \%, 0.17 \%, 0 \%, 0.182 \%$, and $0.1 \%$ for Northern, Southern, Moharaq, Middle, and conventional farms, respectively. For sheep, RBPT indicated that $10 / 3420(0.292 \%)$ animals were seropositive. The prevalence was $0.38 \%, 0.33 \%$, $0 \%, 0.15 \%$, and $0.34 \%$ for Northern, Southern, Moharaq, Middle, and conventional farms, respectively. Results confirmed by i-ELISA showed that $5 / 3420(0.15 \%)$ sheep were seropositive. The prevalence was $0.13 \%, 0.22 \%, 0 \%, 0.15 \%$, and $0.11 \%$ for Northern, Southern, Moharaq, Middle, and conventional farms, respectively.

RBPT results showed that $3 / 1580(0.19 \%)$ goats were seropositive. The prevalence was $0.28 \%, 0 \%$, $0 \%, 0.24 \%$, and $0 \%$ Northern, Southern, Moharaq, Middle, and conventional farms, respectively. i-ELISA confirmed all positive sera identified by RBPT.

For Group 2 (quarantine), RBPT identified $49 / 3500(1.4 \%)$ animals and $1.19 \%$ and $2.71 \%$ for sheep and goats, respectively, as seropositive. For i-ELISA, 33/3500 (0.94\%) and $0.83 \%$ and $1.67 \%$ for sheep and goats, respectively, were confirmed (Tables-4 and 6, Figures-4-6)

\section{Farm view rates}

Examining data by showed 5/259 (1.93\%) of farms were seropositive by RBPT for one or more animals. Two, 1, 0, 1, and 1 farms show the prevalence Brucella of $2.35 \%, 1.39 \%, 0 \%, 1.61 \%$, and $12.5 \%$ in Northern, Southern, Moharaq, Middle, and conventional farms, respectively. i-ELISA confirmed that 4/259 (1.54\%) of farms were seropositive. The one farm that was not confirmed was in the Northern Territory (Table-8). RBPT analyses for sheep farms showed that 4/245 (1.68\%) farms were seropositive. One, $1,0,1$, and 1 farms show the prevalence of $1.35 \%, 1.45 \%, 0 \%, 1.33 \%$, and $12.5 \%$ in Northern, Southern, Moharaq, Middle, and conventional farms. i-ELISA confirmed all RBPT results (Table-9). RBPT analyses found that 2/128 $(1.56 \%)$ farms were seropositive. One, $0,0,1$, and 0 farms show the prevalence of $1.92 \%, 0 \%, 0 \%, 2.56 \%$, and $0 \%$ in Northern, Southern, Moharaq, Middle, and conventional farms, respectively. The same result was obtained when confirmed by i-ELISA (Table-10).

\section{Sex-related rate}

RBPT analyses found that $1 / 423(0.24 \%)$ males were seropositive with the single positive result from an animal in the Northern Territory. In contrast, $12 / 4577(0.26 \%)$ female animals were seropositive. The prevalence was $0.3 \%, 0.28 \%, 0 \%, 0.2 \%$, and $0.31 \%$ in Northern, Southern, Moharaq, Middle, and conventional farms, respectively.

i-ELISA did not confirm the single seropositive result in the male animals. Eight of $4577(0.16 \%)$ females were seropositive in i-ELISA. The prevalence was $0.22 \%, 0.19 \%, 0 \%, 0.2 \%$, and $0.1 \%$ in Northern, Southern, Moharaq, Middle, and conventional farms, respectively.

For Group 2 (quarantine), 47/3450 (1.36\%) and $32 / 3450(0.93 \%)$ male animals were identified by RBPT and i-ELISA, respectively, and were $2 / 50$ $(4.0 \%)$ and $1 / 50(2.0 \%)$ female animals using RBPT and i-ELISA, respectively (Table-11 and Figure-7).

\section{PCR results}

PCR confirmed brucellosis in blood samples in 41 samples that were positive in RBPT and i-ELISA analyses. PCR confirmed 18/8500 samples $(0.21 \%$, CI 95\% 0.13-0.34). Three of 5000 (CI 95\%, 0.019$0.19)$ and $15 / 3500(0.43 \%$, CI 95\% 0.26-0.71) were confirmed animals from Group 1 (farms) and Group 2 (quarantine), respectively. Fifteen of 6441 (0.466\%) samples from sheep were confirmed with $2 / 4320$ $(0.06 \%)$ and $13 / 3021(0.43 \%)$ in animals from farms 
Table-6: i-ELISA test results.

\begin{tabular}{|c|c|c|c|c|c|c|c|c|}
\hline \multirow[t]{2}{*}{ Group } & \multirow[t]{2}{*}{ Type } & \multirow[t]{2}{*}{ Territory } & \multicolumn{6}{|c|}{ i-ELISA results } \\
\hline & & & Total & $\%$ & Sheep & $\%$ & Goats & $\%$ \\
\hline \multirow[t]{6}{*}{ Group 1} & Unorganized farms & Northern terr. & 3 & 0.20 & 1 & 0.13 & 2 & 0.28 \\
\hline & & Southern terr. & 2 & 0.17 & 2 & 0.22 & 0 & 0.00 \\
\hline & & Moharaq terr. & 0 & 0.00 & 0 & 0.00 & 0 & 0.00 \\
\hline & & Middle terr. & 2 & 0.18 & 1 & 0.15 & 1 & 0.24 \\
\hline & Organized farms & & 1 & 0.10 & 1 & 0.11 & 0 & 0.00 \\
\hline & Total (Group 1) farms & & 8 & 0.16 & 5 & 0.15 & 3 & 0.19 \\
\hline Group 2 & Quarantine & & 33 & 0.94 & 25 & 0.83 & 8 & 1.67 \\
\hline Total & & & 41 & 0.48 & 30 & 0.47 & 11 & 0.53 \\
\hline
\end{tabular}

i-ELISA =Indirect enzyme-linked immunosorbent assay

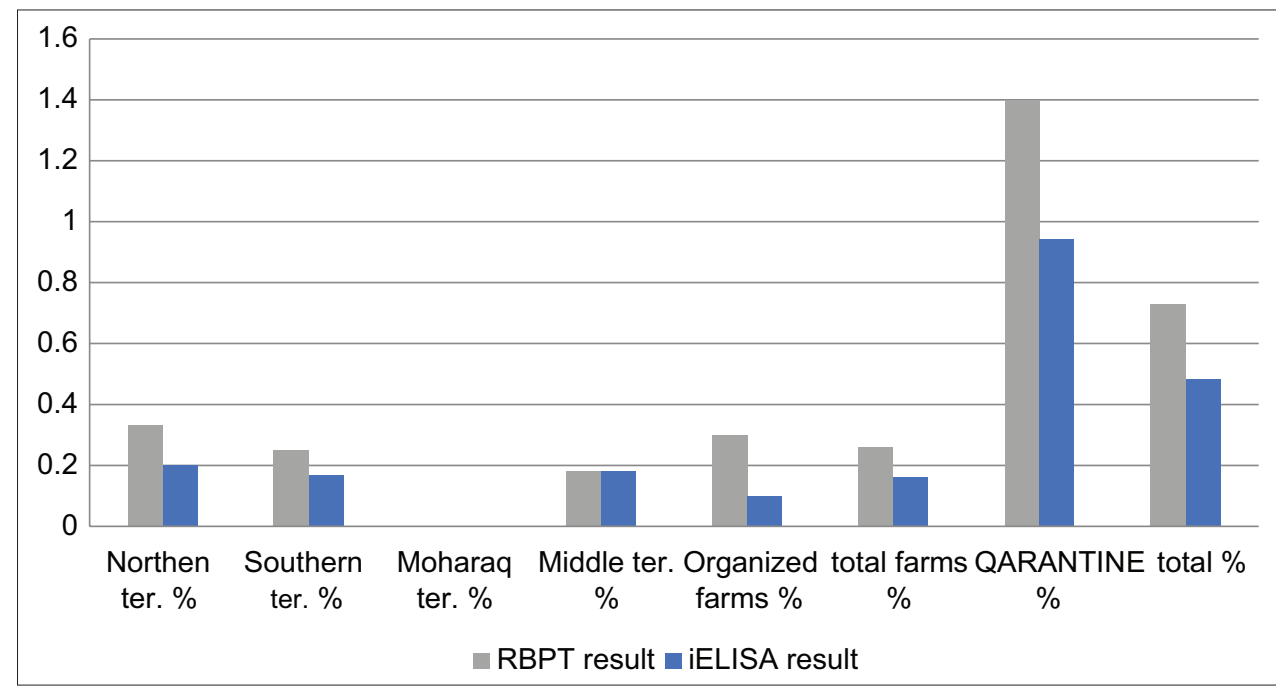

Figure-4: Chart of total infection rates by Rose Bengal Plate Test and indirect enzyme-linked immunosorbent assay.

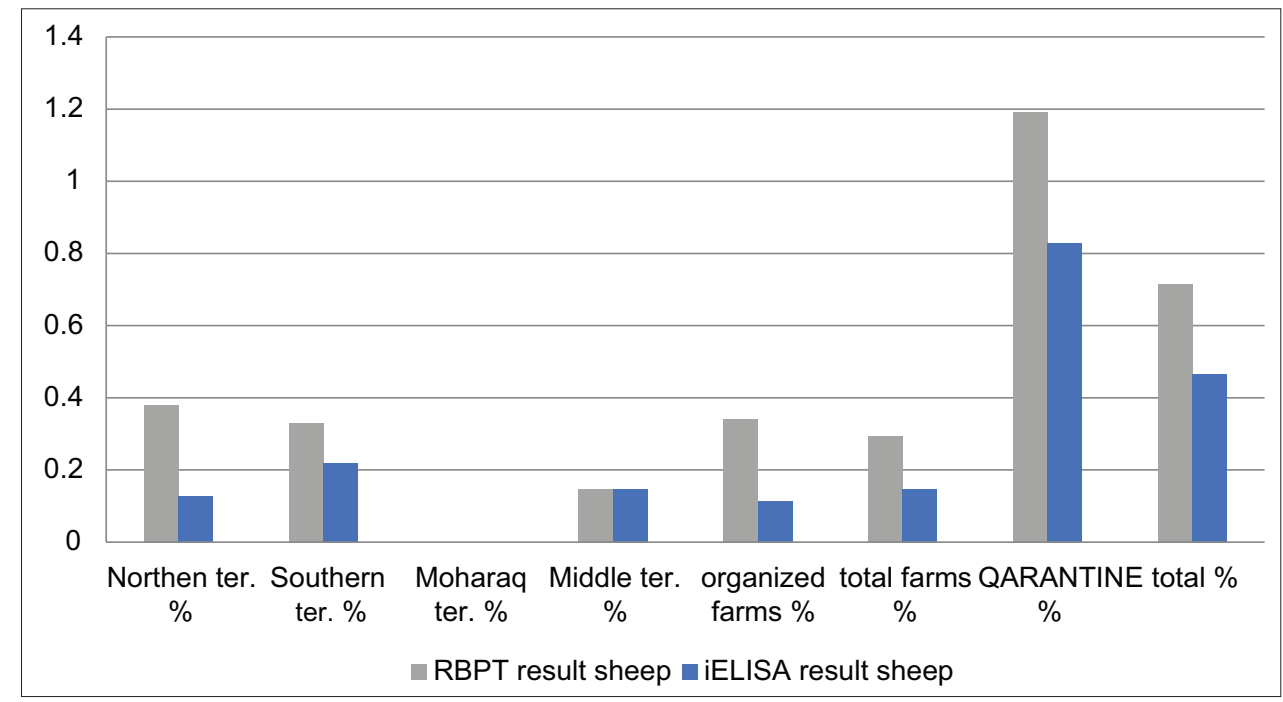

Figure-5: Chart of infection rates by Rose Bengal Plate Test and indirect enzyme-linked immunosorbent assay in sheep.

and quarantine, respectively. Confirmation results for goats were $3 / 2059(0.146 \%), 1 / 1580(0.06 \%)$, and $2 / 479(0.42 \%)$ total, farm, and quarantine animals, respectively (Tables-12 and 13).

\section{Tests on tissue samples}

Brucella isolation and identification

Brucella was isolated and identified for brucellosis in tissue samples from 14 to 30 culled or slaughtered animals that were seropositive by RBPT and
i-ELISA. All B. melitensis isolates were Biovar 1 and were less prevalent in farm animals $(3 / 5000,0.06 \%)$ than quarantined animals $(11 / 3500,0.31 \%)$. Eleven of 6441 sheep $(0.18 \%)$ were confirmed positive, $2 / 4320$ $(0.07 \%)$ and $9 / 3021(0.3 \%)$ from Group 1 (farms) and Group 2 (quarantine), respectively. The results for goats were $3 / 2059(0.16 \%), 1 / 1580(0.072 \%)$, and $2 / 479(0.42 \%)$ for total, farm, and quarantined animals, respectively (Table-14). 


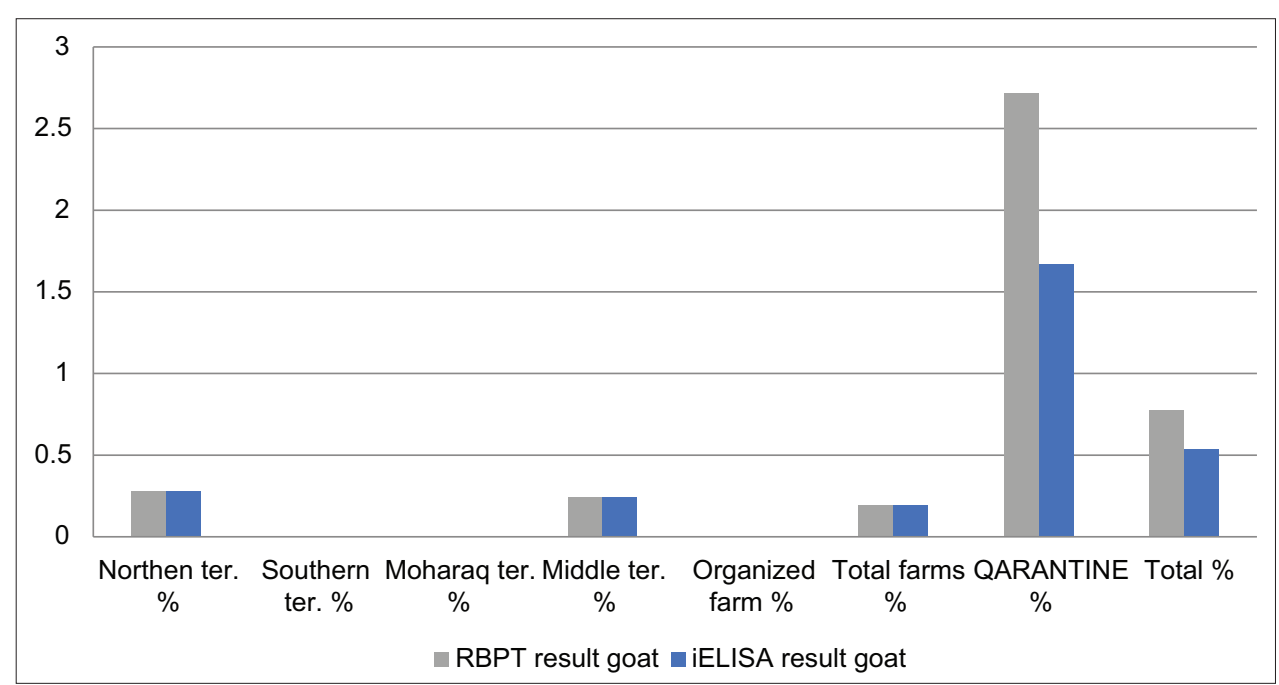

Figure-6: Chart showing infection rates by Rose Bengal Plate Test and indirect enzyme-linked immunosorbent assay in goats.

Table-7: i-ELISA test result CI 95\%.

\begin{tabular}{|c|c|c|c|}
\hline & $\begin{array}{l}\text { Group } 1 \\
\text { farms }\end{array}$ & $\begin{array}{c}\text { Group } 2 \\
\text { Quarantine }\end{array}$ & Total \\
\hline $\begin{array}{l}\text { Number of positive } \\
\text { i-ELISA }\end{array}$ & $8 / 5000$ & $33 / 3500$ & $41 / 8500$ \\
\hline$\%$ & 0.16 & 0.94 & 0.48 \\
\hline CI 95 & $0.08-0.32$ & $0.67-1.3$ & $0.36-0.65$ \\
\hline $\begin{array}{l}\text { Number of positive } \\
\text { i-ELISA Sheep }\end{array}$ & $5 / 3420$ & $25 / 3021$ & $30 / 6441$ \\
\hline$\%$ & 0.15 & 0.83 & 0.47 \\
\hline CI 95 & $0.06-0.35$ & $0.56-1.2$ & $0.33-0.67$ \\
\hline $\begin{array}{l}\text { Number of positive } \\
\text { i-ELISA goats }\end{array}$ & $3 / 1580$ & 8/479 & $11 / 2059$ \\
\hline$\%$ & 0.19 & 1.67 & 0.53 \\
\hline CI 95 & $0.06-0.59$ & $0.84-3.32$ & $0.3-0.96$ \\
\hline
\end{tabular}

$\mathrm{CI}=$ Confidence interval, $\mathrm{i}$-ELISA=Indirect enzyme-linked immunosorbent assay

\section{PCR for tissue samples}

PCR confirmed B. melitensis in 23/30 tissue samples $(0.27 \%)$ with $4 / 5000(0.08 \%)$ and $19 / 3500$ $(0.54 \%)$ in animals from Group 1 (farms) and Group 2 (quarantine), respectively (Table-14). Eighteen of $6441(0.28 \%)$ sheep were confirmed with $3 / 4320$ $(0.09 \%)$ and $15 / 3021(0.5 \%)$ in sheep from Group 1 (farms) and Group 2 (quarantine), respectively. The results were $5 / 2059(0.26 \%)$ for goats with $1 / 1580$ $(0.08 \%)$ and $4 / 479(0.84 \%)$ in animals from farms and quarantine (Table-14).

\section{Discussion}

Brucellosis is an important zoonosis that causes abortion in naturally infected small ruminants and is of great public health concern in many countries [30,31]. The results of the study were part of an effort to develop a method for rapid and accurate brucellosis diagnosis. Such a method is critical to support effective eradication and monitoring programs.

Many factors that affect brucellosis seroprevalence in small ruminants could be associated with frequent introduction of purchased animals into flocks, including the absence of quarantine/segregation, mixing of different species of infected flocks, improper safe hygienic disposal of aborted fetuses placental membranes, contact of healthy animals with contaminated drinking water, grassing yards and feed, and lack of vaccination and control strategies for small ruminants [30-32].

Brucellosis control and eradication from small ruminants (sheep and goats) require an appropriate serological method for brucellosis diagnosis in the infected or endemic areas. Diagnostic tests used may not reveal all animals infected (false-negatives) or may show infection when it not present (false-positives) due to a long period of incubation, latency, or criteria used to interpret the results [31,32]. Isolation and identification of organisms are the diagnosis gold standard, but it is cumbersome, takes several days to weeks, and poses a higher risk to laboratory personnel. Hence, the diagnosis of brucellosis largely depends on the use of two or more tests to confirm infection [32]. RBPT is a current screening test, and i-ELISA is used as a confirmatory test used for $B$. melitensis infection in small ruminants (sheep and goats) [31-36]. In comparison to i-ELISA, Sn, and Sp of the RBPT are lower. However, RBPT is convenient because of low cost, feasibility, and reliability as a field diagnostic test compared with i-ELISA $[37,38]$. The latter technique provides acceptable sensitivity and specificity $[39,40]$.

The overall brucellosis prevalence seropositivity in the study area was $0.48 \%$ by RBT and i-ELISA, which is lower than that found in Al-Ahsa KSA which was 1.1\% [41], Alkamil, KSA 5.88\% [10], Abu Dhabi Emirate 8.3\% [42], Oman 2.4\%, (Dhofar) 8.6\%, Northern governorates $0.97 \%$, Al Aqaieb 24\%, and Al Helailat 40\%. While in Al Ghilayil, Al Qasha'e, Da'anAlhamra, Al Sarah, Hail Al Hedap, and Shnoot are free from brucellosis $[13,43]$.

Brucella infection seroprevalence in small ruminants was determined based on screening with RBPT 


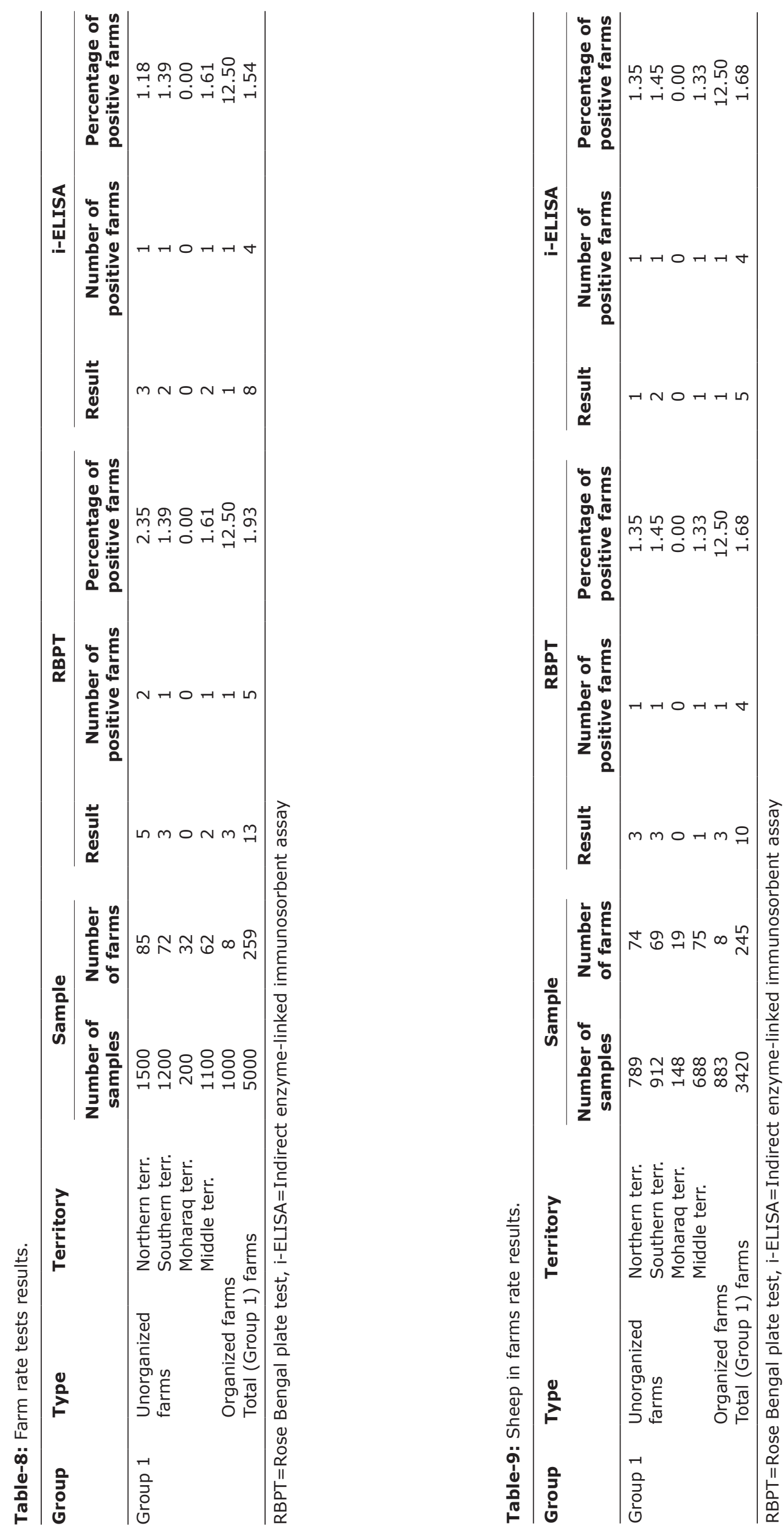




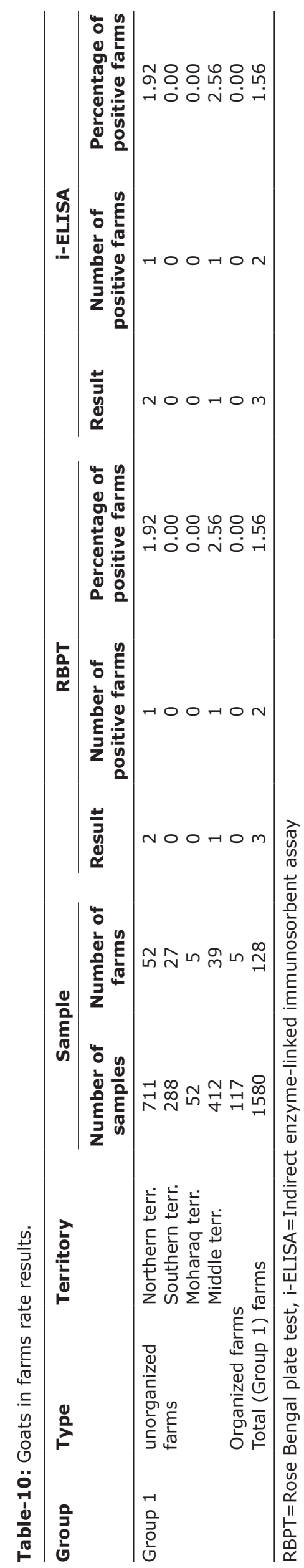

and confirmation by i-ELISA. Twenty-one samples tested positive by RBPT but negative by i-ELISA. The higher sensitivity of i-ELISA due to its recognition of cytosolic antigen S-LPS fragments may decrease cross-reaction with other Gram-negative bacteria $[5,44,45]$. Other bacteria share similar epitopes with Brucella [5].

Secondary can refer acidified antigens in RPBT usually produce prozoning phenomena (false positive result), [44]. Hence, i- ELISA has been evaluated for many years for their better sensitivity to detect anti-Brucella antibodies in all species especially small ruminant, several studies reported that i-ELISA is more sensitive than conventional tests [13] assessed the indirect ELISA efficacy in comparison with CFT and RBPT on sera from $B$. melitensis infected ewes. Indirect ELISA can be a useful screening tool and could be used alone or in addition to RBT. The present i-ELISA performance is consistent with the study of Nielsen et al. [46]. The performance evaluation of infected and vaccinated sheep and goats showed that i-ELISA outperformed other tests and recommended it for diagnosis of Ovine-Caprine brucellosis. However, low performance with vaccinated animals limits i-ELISA to instances where animals have no history of vaccination to avoid false-positive results $[11,47]$.

Estimated infection rates in sheep were $0.71 \%$ and $0.47 \%$ by RBT and i-ELISA, respectively, and in goats, $0.78 \%$ and $0.53 \%$ by RBT and i-ELISA, respectively. No significant difference existed between these species. Furthermore, a significant difference was observed between species in Group 2 (quarantine). Results for goats $(2.7 \%)$ and $(1.7 \%)$ were higher than for sheep (1.2) and (0.8\%) by RBT and i-ELISA, respectively. This result may reflect infection rates in the country of origin and local control programs. Sheep and goats were imported from different countries. In contrast, a higher prevalence of sheep has also been reported $[38,41,43]$.

Sheep behavior may also be a factor since they tend to gather in parturition and at night, which increases the potential for disease transmission. Goats do not display this behavior [48]. Larger herds of sheep may be more likely to show at least one positive case than small herds and are typically associated with mass livestock management. Infection in these herds may spread due to closer contact among animals and their Brucella-containing excretions [49].

Seroprevalence was not significantly different between males and females in Group 1 (farms) but showed a higher incidence in males in Group 2 (quarantine). This result contrasts with other reports $[6,50,51]$. Statistical analysis shows that males and females are equally susceptible to Brucella infection. Thus, the present results may be affected by the small number of males examined from farms and the few females from quarantine.

Serological testing with RBT and i-ELISA for Brucella infections is widely accepted. However, 
Table-11: Male and female rate.

\begin{tabular}{|c|c|c|c|c|c|c|c|c|c|c|c|}
\hline \multirow[t]{2}{*}{ Group } & \multirow[t]{2}{*}{ Type } & \multirow[t]{2}{*}{ Territory } & \multicolumn{3}{|c|}{ Sample } & \multicolumn{3}{|c|}{ RBPT } & \multicolumn{3}{|c|}{ i-ELISA } \\
\hline & & & $\begin{array}{c}\text { Number } \\
\text { of } \\
\text { samples }\end{array}$ & $\begin{array}{c}\text { Number } \\
\text { of } \\
\text { sample } \\
\text { male }\end{array}$ & $\begin{array}{c}\text { Number } \\
\text { of } \\
\text { sample } \\
\text { female }\end{array}$ & $\begin{array}{l}\text { RBPT } \\
\text { result }\end{array}$ & $\begin{array}{c}\text { RBPT } \\
\text { result } \\
\text { male }\end{array}$ & $\begin{array}{c}\text { RBPT } \\
\text { result } \\
\text { female }\end{array}$ & $\begin{array}{c}\text { i-ELISA } \\
\text { result }\end{array}$ & $\begin{array}{c}\text { i-ELISA } \\
\text { result } \\
\text { male }\end{array}$ & $\begin{array}{c}\text { i-ELISA } \\
\text { result } \\
\text { female }\end{array}$ \\
\hline \multirow[t]{11}{*}{ Group 1} & $\begin{array}{l}\text { Unorganized } \\
\text { farms }\end{array}$ & $\begin{array}{l}\text { Northern } \\
\text { terr. }\end{array}$ & 1500 & 150 & 1350 & 5 & 1 & 4 & 3 & 0 & 3 \\
\hline & & $\begin{array}{l}\text { Northern } \\
\text { terr. \% }\end{array}$ & & & & 0.33 & 0.67 & 0.30 & 0.20 & 0.00 & 0.22 \\
\hline & & $\begin{array}{l}\text { Southern } \\
\text { terr. }\end{array}$ & 1200 & 123 & 1077 & 3 & 0 & 3 & 2 & 0 & 2 \\
\hline & & $\begin{array}{l}\text { Southern } \\
\text { ter. \% }\end{array}$ & & & & 0.25 & 0.00 & 0.28 & 0.17 & 0.00 & 0.19 \\
\hline & & $\begin{array}{l}\text { Moharaq } \\
\text { terr. }\end{array}$ & 200 & 38 & 162 & 0 & 0 & 0 & 0 & 0 & 0 \\
\hline & & $\begin{array}{l}\text { Moharaq } \\
\text { terr. \% }\end{array}$ & & & & 0.00 & 0.00 & 0.00 & 0.00 & 0.00 & 0.00 \\
\hline & & $\begin{array}{l}\text { Middle } \\
\text { terr. }\end{array}$ & 1100 & 87 & 1013 & 2 & 0 & 2 & 2 & 0 & 2 \\
\hline & & $\begin{array}{l}\text { Middle } \\
\text { terr. \% }\end{array}$ & & & & 0.18 & 0.00 & 0.20 & 0.18 & 0.00 & 0.20 \\
\hline & \multicolumn{2}{|c|}{ Organized farms } & 1000 & 25 & $\begin{array}{l}975 \\
0.30\end{array}$ & $\begin{array}{c}3 \\
0.00\end{array}$ & $\begin{array}{c}0 \\
0.31\end{array}$ & $\begin{array}{c}3 \\
0.10\end{array}$ & $\begin{array}{c}1 \\
0.00\end{array}$ & $\begin{array}{c}0 \\
0.10\end{array}$ & 1 \\
\hline & \multirow{2}{*}{\multicolumn{2}{|c|}{$\begin{array}{l}\text { Total farms } \\
\text { Total farms \% }\end{array}$}} & 5000 & 423 & 4577 & 13 & 1 & 12 & 8 & 0 & 8 \\
\hline & & & & & & 0.26 & 0.24 & 0.26 & 0.16 & 0.00 & 0.17 \\
\hline \multirow{2}{*}{ Group 2} & \multirow{2}{*}{\multicolumn{2}{|c|}{$\begin{array}{l}\text { Quarantine } \\
\text { Quarantine \% }\end{array}$}} & 3500 & 3450 & 50 & 49 & 47 & 2 & 33 & 32 & 1 \\
\hline & & & & & & 1.40 & 1.36 & 4.00 & 0.94 & 0.93 & 2.00 \\
\hline Total & & & 8500 & 3873 & 4627 & 62 & 48 & 14 & 41 & 32 & 9 \\
\hline Total \% & & & & & & 0.73 & 1.24 & 0.30 & 0.48 & 0.83 & 0.19 \\
\hline
\end{tabular}

RBPT=Rose Bengal plate test, i-ELISA=Indirect enzyme-linked immunosorbent assay

Table-12: PCR results blood samples.

\begin{tabular}{|c|c|c|c|c|c|c|c|c|}
\hline \multirow[t]{2}{*}{ Group } & \multirow[t]{2}{*}{ Type } & \multirow[t]{2}{*}{ Area } & \multicolumn{6}{|c|}{ PCR serum } \\
\hline & & & Total & $\%$ & Sheep & $\%$ & Goats & $\%$ \\
\hline \multirow[t]{6}{*}{ Group 1} & Unorganized farms & Northern terr. & 1 & 0.07 & 0 & 0.00 & 1 & 0.14 \\
\hline & & Southern terr. & 1 & 0.08 & 1 & 0.11 & 0 & 0 \\
\hline & & Moharaq terr. & 0 & 0 & 0 & 0 & 0 & 0 \\
\hline & & Middle terr. & 1 & 0.09 & 1 & 0.15 & 0 & 0 \\
\hline & Organized farms & & 0 & 0 & 0 & 0 & 0 & 0 \\
\hline & Total (Group 1) farms & & 3 & 0.06 & 2 & 0.06 & 1 & 0.06 \\
\hline Group 2 & Quarantine & & 15 & 0.43 & 13 & 0.43 & 2 & 0.42 \\
\hline Total & & & 18 & 0.21 & 15 & 0.23 & 3 & 0.15 \\
\hline
\end{tabular}

$\mathrm{PCR}=$ Polymerase chain reaction

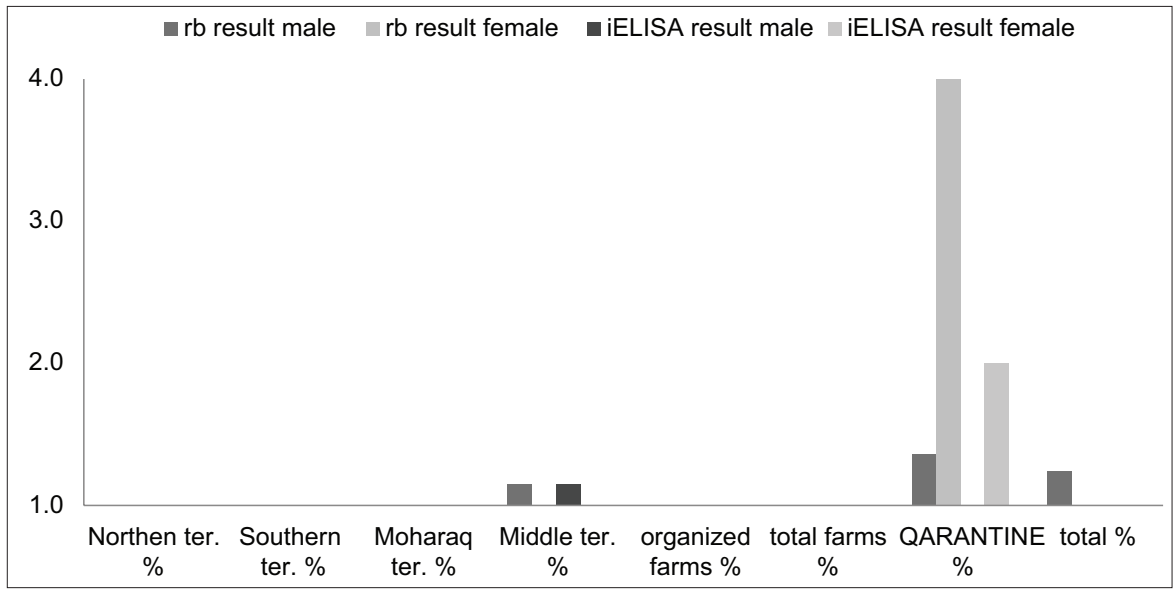

Figure-7: Chart showing male and female rate.

serum agglutination tests (and to a lesser extent RBPT) are less suitable for diagnosis of chronic brucellosis since they mainly depending on $\operatorname{IgM}$ and $\mathrm{IgG}$ detection. IgM found in sera in chronic infection 
Table-13: PCR results blood samples CI 95\%.

\begin{tabular}{|c|c|c|c|c|c|c|}
\hline \multirow[t]{2}{*}{ Group } & \multicolumn{6}{|c|}{ PCR serum } \\
\hline & Total & $\%$ & Sheep & $\%$ & Goats & $\%$ \\
\hline Group 1 farms & $\begin{array}{c}3 / 5000 \\
\text { CI } 95\end{array}$ & $\begin{array}{c}0.06 \\
0.019-0.19\end{array}$ & 2 & 0.06 & 1 & 0.06 \\
\hline Group 2 Quarantine & $\begin{array}{c}15 / 3500 \\
\text { CI } 95\end{array}$ & $\begin{array}{c}0.43 \\
0.26-0.71\end{array}$ & 13 & 0.43 & 2 & 0.42 \\
\hline Total & $\begin{array}{l}18 / 8500 \\
\text { CI } 95\end{array}$ & $\begin{array}{c}0.21 \\
0.13-0.34\end{array}$ & 15 & 0.23 & 3 & 0.15 \\
\hline
\end{tabular}

$\mathrm{PCR}=$ Polymerase chain reaction, $\mathrm{CI}=$ Confidence interval

Table-14: Results of tissue samples examination.

\begin{tabular}{|c|c|c|c|c|c|c|c|c|}
\hline \multirow[t]{2}{*}{ Group } & \multirow[t]{2}{*}{ Type } & \multirow[t]{2}{*}{ Territory } & \multicolumn{3}{|c|}{ Media culture } & \multicolumn{3}{|c|}{ PCR t. sample } \\
\hline & & & Total & Sheep & Goats & Total & Sheep & Goats \\
\hline \multirow[t]{12}{*}{ Group 1} & Unorganized & Northern terr. & 2 & 1 & 1 & 1 & 1 & 0 \\
\hline & farms & Northern terr. \% & 0.13 & 0.13 & 0.14 & 0.07 & 0.13 & 0 \\
\hline & & Southern terr. & 1 & 1 & 0 & 1 & 1 & 0 \\
\hline & & Southern terr. \% & 0.08 & 0.11 & 0 & 0.08 & 0.11 & 0 \\
\hline & & Moharaq terr. & 0 & 0 & 0 & 0 & 0 & 0 \\
\hline & & Moharaq terr. \% & 0 & 0 & 0 & 0 & 0 & 0 \\
\hline & & Middle terr. & 0 & 0 & 0 & 1 & 0 & 1 \\
\hline & & Middle terr. \% & 0 & 0 & 0 & 0.09 & 0 & 0.24 \\
\hline & Organized farms & & 0 & 0 & 0 & 1 & 1 & 0 \\
\hline & Organized farms \% & & & 0 & 0 & 0.10 & 0.11 & 0 \\
\hline & Total farms & & 3 & 2 & 1 & 4 & 3 & 1 \\
\hline & Total farms \% & & 0.06 & 0.07 & 0.07 & 0.08 & 0.09 & 0.08 \\
\hline \multirow[t]{2}{*}{ Group 2} & Quarantine & & 11 & 9 & 2 & 19 & 15 & 4 \\
\hline & Quarantine \% & & 0.31 & 0.30 & 0.42 & 0.54 & 0.50 & 0.84 \\
\hline Total & & & 14 & 11 & 3 & 23 & 18 & 5 \\
\hline Total \% & & & 0.17 & 0.18 & 0.16 & 0.27 & 0.28 & 0.26 \\
\hline
\end{tabular}

$\mathrm{PCR}=$ Polymerase chain reaction

will decline and become undetectable [50]. ELISA remains a useful epidemiological tool that provides for investigation of the infective status of herds [5,51-56].

Information on Brucella prevalence in small ruminants (goats and sheep) is critical to preventive control measures for brucellosis. However, seroprevalence information for brucellosis in the gulf province has been scant, though small ruminants are major livestock and traditionally the main sources of meat. Infection is often under-detected in this region despite inflicting a high economic and health burden, mainly due to a lack of concern at the individual level in rural areas. Moreover, the present study results are useful for policymakers to evaluate the status of the disease in livestock. Finally, the study provides baseline data for further study of Brucella infections and for planning control and eradication strategies.

PCR and other genetic techniques are broadly used for the rapid detection of brucellosis [57] and could be considered in future studies in the gulf. PCR confirmed brucellosis in blood samples in 18 of 41 samples that were seropositive by RBPT and i-ELISA. Of these samples, 3 and 15 were confirmed positive in animals from farms and quarantine, respectively. Fifteen sheep were confirmed positive, 2 and 13 in animals from farms and quarantine, respectively. Three samples from goats $3 / 2059(0.146 \%)$ were confirmed positive, with one from farms. The results indicate that diagnosis of brucellosis by PCR using blood as a sample is applicable but not simple. In the present investigation, further effort was made for diagnosing brucellosis from blood samples [22,57].

Only 18 samples were positive by PCR compared to 62 by RBPT and 41 by i-ELISA. Wide variation in samples detected could be due to many factors. PCR detects DNA, which may be in low quantity in blood samples even though antibody titer is quite high. Alternatively, titer in serum may be below detectable levels, but the amount of DNA may be sufficient for detection by PCR. PCR may detect as little as five fg of DNA [58]. Furthermore, standardized conditions for RBPT antigen suitable for diagnosing bovine infection are not adequate for sheep and accounts for the low sensitivity of RBPT in small ruminants [59]. This report is preliminary and indicates that PCR can also be applied for the diagnosis of brucellosis in animals, using blood samples, for more rapid and accurate brucellosis diagnosis.

From 30 tissue samples collected from culled or slaughtered animals that were seropositive, only 23 samples were detected as positive by PCR. Thus, PCR did not identify seven seropositive samples as positive. Isolation identified only 14 samples of $B$. melitensis, and confirmed Biovar 1. No bacteria could be isolated from 16 seropositive samples. Isolation and cultivation are a gold standard diagnostic technique for 
brucellosis since it is specific and permits biotyping to aide epidemiological analysis [60]. Only the organism can provide a definitive profile and firm confirmation of infection. However, negative result does not exclude the presence of brucellosis [61]. Typing of Brucella was performed for strains isolated from tissue samples and lymph nodes from slaughtered animals verified to be serologically positive. All isolates were typical of $B$. melitensis and were identified as Br. melitensis Biovar 1. These results are consistent with the previous reports [61-64]. The primary hosts for $B$. melitensis are small ruminants, suggesting that the sensitivity of serological tests is higher than that of the culture method. A similar conclusion was reached by Sayour [62], who concluded that the best specific diagnostic assay is the isolation of the causative organism; however, this method suffers the disadvantages of low sensitivity and a requirement for extended time for tissue preparation and culture.

Some research indicates that PCR-ELISA is more sensitive than other molecular methods. This method is more effective and accurate than PCR, serology, and culture of bacteria [65]. PCR is more sensitive and easily applicable than bacterial culture $[6,11]$. Further, some studies indicate a real transmission risk to both butchery personnel and consumers. Accurate and sensitive testing of animals before slaughter and marketing is needed to prevent the spread of human infection [66].

\section{Conclusion}

The overall incidence of brucellosis is $0.48 \%$, and $0.16 \%$ in farms. In this area of the gulf, the disease seems to be under control, and a continuous effort is needed to maintain control and eventually completely eradicate brucellosis. Additional support is needed for testing and slaughterhouse monitoring. In quarantined (imported) animals, brucellosis infection in the slaughterhouse $(0.94 \%)$ could pose a risk for transmission and spread of infection. Effort is needed to monitor this threat, and PCR is a sensitive and time-saving test for brucellosis diagnosis. All 14 confirmed positive samples were Biovar 1 dominant.

\section{Authors' Contributions}

ME, AE, and FS planned the study. ME collected the samples, performed the experiments, processed the experimental data, performed the analysis, drafted the manuscript, and designed the figures and performed the calculations. AE and FS supervised the findings of this work. All authors discussed the results and contributed to the final manuscript.

\section{Acknowledgments}

The authors are grateful to Prof. Dr. Tamer Mohamed for his help in data analysis. The present study was a part of brucellosis control and eradication project work in Gulf Cooperation Council area. The authors did not receive any funds for this study.

\section{Competing Interests}

The authors declare that they have no competing interests.

\section{Publisher's Note}

Veterinary World remains neutral with regard to jurisdictional claims in published institutional affiliation.

\section{References}

1. Radostits, O.M., Gay, C., Blood, C.D. and Hinchclift, W.K. (2007) Veterinary Medicine, Textbook of the Diseases of Cattle, Sheep, Pigs, Goats and Horses. 10 ${ }^{\text {th }}$ ed. ELBS Bailliere Tindall, London, UK. p963-994.

2. Rossetti, C.A., Arenas-Gamboa, A.M. and Maurizio, E. (2017) Caprine brucellosis: A historically neglected disease with significant impact on public health. PLoS Negl. Trop. Dis., 11(8): e0005692.

3. World Health Organization. (2006) Brucellosis in Humans and Animals. World Health Organization, Geneva, Switzerland.

4. World Health Organization. (2009) Integrated Control of Neglected Zoonotic Diseases in Africa: Applying the One Health Concept. WHO Document Production Services, Geneva, Switzerland.

5. OIE. (2018) Manual of Standards for Diagnostic Tests and Vaccines for Terrestrial Animals. Ch. 2.1.4. Brucellosis (Brucella abortus, B. melitensis and B. suis) (infection with B. abortus, B. melitensis and B. suis). OIE, Paris, France.

6. Samadi, A., Ababneh, M.M.K., Giadinis, N.D. and Lafi, S.Q. (2010) Ovine and caprine brucellosis (Brucella melitensis) in aborted animals in Jordanian sheep and goat flocks. Vet. Med. Int. Volume 2010 |Article ID 458695 | 7 pages.

7. Rubach, P., Halliday, J.E.B., Cleaveland, S. and Crump, J.A. (2013) Brucellosis in low-income and middle-income countries. Curr. Opin. Infect. Dis., 26(5): 404-412.

8. Godfroid, J. (2017) Brucellosis in livestock and wildlife: Zoonotic diseases without pandemic potential in need of innovative one health approaches. Arch. Public Health, 75(1): 34 .

9. Mohamed, E.M.A., Elfadil, A.A.M., El-Sanousi, E.M., Ibrahaem, H.H., Mohamed-Noor, E.E., Abdalla, M.A. and Shuaib, Y.A. (2018) Seroprevalence and risk factors of caprine brucellosis in Khartoum state, Sudan. Vet. World, 11(4): 511-518.

10. Kandeel, A.E., Gamal, M.T., Sediek, A.A., Salauddin, H.S. and Fadlelmoula, A.A.A. (2014) Seroprevalence of brucellosis within sheep and goat flocks in Alkamil province in Saudi Arabia. Bothalia J., 44(5): 131-138.

11. El-Sharkawy, H., Ahmed, S.A., Salem, M.A.M., Soliman, S.M. and Soliman, H.S. (2019) Some Epidemiological Studies on Sheep and Goats Brucellosis in Egypt. Ph.D. Thesis, Cairo University, Egypt.

12. Shuaib, Y.A., Mansour, M.E., Ibrahaem, H.H., MohamedNoor, S.E., Boukhari, M.I., Issa, M.H., El-Sanousi, E.M., Suliman, S.E., El-Fadil, A.A.M. and Abdalla, M.A. (2018) Seroprevalence of sheep brucellosis in three different locations in Kassala state: A Short communication. J. Dairy Vet. Anim. Res., 7(2): 53-57.

13. ElTahir, Y., Al Toobi, A.G., Al-Marzooqi, W., Mahgoub, O., Jay, M., Corde, Y., Al Lawati, H., Bose, S., Al Hamrashdi, A., Al Kharousi, K., Al-Saqri, N., Al Busaidi, R. and Johnson, E.H. (2018) Serological, cultural and molecular evidence of Brucella melitensis infection in goats in Al Jabaal Al Akhdar, Sultanate of Oman. Vet. Med. Sci., 4(3): 190-120.

14. Olufemi, O.T., Dantala, D.B., Shinggu, P.A., Dike, U.A., Otolorin, G.R., Nwuku, J.A., Baba-Onoja, E.B.T., Jatau, T.D. and Amama, F.I. (2018) Seroprevalence of 
brucellosis and associated risk factors among indigenous breeds of goats in Wukari, Taraba State. Niger. J. Pathog., Volume 2018 |Article ID 5257926 | 5 pages.

15. Abdalla, M.A., El-Sanousi, E.M., Shuaib, Y.A., Ibrahaem H.H., Fadle-Al-Mola, K.M., MohamedNoor, S.E., Suliman, S.E., Idris, S.H. and Abdalla, M.A. (2019) Sero-prevalence of brucellosis in sheep in El-Gadarif state. EC Vet. Sci., 4(1): 15-19.

16. Saxena, N., Singh, B.B. and Saxena, H.M. (2018) Brucellosis in sheep and goats and its serodiagnosis and epidemiology. Int. J. Curr. Microbiol. Appl. Sci., 7(1): 1848-1877.

17. El-Diasty, M.M., Wareth, G., Melzer, F., Mustafa, S., Sprague, L.D. and Neubauer, H. (2018) Isolation of Brucella abortus and Brucella melitensis from seronegative cows is a serious impediment in brucellosis control. Vet. Sci., 5(1): 28.

18. Elfaki, M.G., Al-Hokail, A., Nakeeb, S.M. and Al-Rabiah, F.A. (2005) Evaluation of culture, tube agglutination, and PCR methods for the diagnosis of brucellosis in humans. Int. Med. J. Exp. Clin. Res., 11(11): 69-74.

19. Wareth, G., Melzer, F., Tomaso, H., Roesler, U. and Neubauer, H. (2015) Detection of Brucella abortus DNA in aborted goats and sheep in Egypt by real-time PCR. BMC Res. Notes, Volume 8, Article number: 212 (2015).

20. Bhandi, S., Pfukenyi, D.M., Matope, G., Murondoti, A., Tivapasi, M., Ndengu, M., Scacchia, M., Bonfini, B. and de Garine-Wichatitsky, M. (2019) Brucellosis and chlamydiosis seroprevalence in goats at livestock wildlife interface areas of Zimbabwe. Onderstepoort J. Vet. Res., 86(1): 1670.

21. Kaden, R., Ferrari, S., Alm, E. and Wahab, T. (2017) A novel real-time PCR assay for specific detection of Brucella melitensis. BMC Infect. Dis., 17(1): 230.

22. Singh, M., Ingh, D.K.S., Shivaramu, K.V., Biswas, R., Rawat, S., Boral, R., Singh, S. and Cheema, P.S. (2010) Serum as clinical specimen in PCR for diagnosis of ovine brucellosis. Indian J. Anim. Sci., 80(1): 17-18.

23. Shakerian, A., Deo, P., Rahimi, E., Shahjavan, A.R. and Khamesipour, F. (2016) Molecular detection of Brucella melitensis in sheep and goat milk in Iran. Trop. J. Pharm. Res., 15(5): 913-918.

24. Sabrina, R., Mossadak, H.T., Bakir, M., Asma, M. and Khaoula, B. (2018) Detection of Brucella spp. in milk from seronegative cows by real-time polymerase chain reaction in the region of Batna, Algeria. Vet. World, 11(3): 363-367.

25. Available from: http://www.climate-data.org(Damamm, Manama). Retrieved on 26-07-2020.

26. Thrusfield, M. (2007) Veterinary Epidemiology. $3^{\text {rd }}$ ed., Ch. 15. United Kingdom, Black Well Science Ltd., p220-221.

27. Ben-Shlomo, Y., Brookes, S. and Hickman, M. (2013) Lecture Notes: Epidemiology, Evidence-Based Medicine and Public Health. $6^{\text {th }}$ ed. Wiley-Blackwell, Oxford.

28. OIE. (2019) Terrestrial Manual Chapter 2.4.3. Bovine Brucellosis. World Organization for Animal Health, OIE, Paris, France.

29. Alton, G.G., Jones, L.M., Angus, R.D. and Verger, J.M. (1988) Techniques for Brucellosis. Institute National de le Recherché Agronomique. de Luniversite, Paris. p75007.

30. Unver, A., Erdogan, H.M., Atabay, H.I., Sahin, M. and Celebi, O. (2006) Isolation, identification, and molecular characterization of Brucella melitensis from aborted sheep fetuses in Kars, Turkey. Rev. Med. Vet., 157(1): 42-46.

31. Benkirane, A., Essamkaoui, S., Idrissi, E.L., Lucchese, L. and Natale, A. (2015) A serosurvey of major infectious causes of abortion in small ruminants in Morocco. Vet. Ital., 51(1): 25-30.

32. Sadhu, D.B., Panchasara, H.H., Chauhan, H.C., Sutariya, D.R., Parmar, V.L. and Prajapati, H.B. (2015) Seroprevalence and comparison of different serological tests for brucellosis detection in small ruminants. Vet. World, 8(5): 561-566.

33. Wogayehu Seria, Yosefdeneke Diriba Tadese, Eshetu Shumi (2020) A Review on Brucellosis in Small Ruminants, American Journal of Zoology, 3(1): 17-25

34. Sharifi, H., Mashayekhi, K. and Tavakoli, M.M. (2015)
Risk factors of small ruminant brucellosis: A cross-sectional study in Southeast Iran 2012. Hum. Vet. Med. Int. J. Bioflux Soc., 7(1): 42-45.

35. Nicoletti, P. (1993) The eradication of brucellosis in animals. Saudi Med. J., 14(4): 288-292.

36. Mahajan, N.K. and Kulshreshtha, R.C. (1991) Comparison of serological tests for Brucella melitensis infection in sheep. Trop. Anim Health Prod., 23(1): 11-16.

37. Kanani, A., Dabhi, S., Patel, Y., Chandra, V., Kumar, O.R.V. and Shome, R. (2018) Seroprevalence of brucellosis in small ruminants in organized and unorganized sectors of Gujarat state, India. Vet. World, 11(8): 1030-1036.

38. Padher, R.R., Nayak, J.B., Brahmbhatt, M.N. and Mathakiya, R.A. (2017) Comparative sensitivity and specificity of various serological tests for detection of brucellosis in small ruminants. Int. J. Curr. Microbiol. Appl. Sci., 6(5): 2090-2099.

39. Radulescu, R.A., Petriceanu, G., Ragalie, A. and Gutu, E. (2007) Comparative evaluation of serological assays for brucellosis diagnosis. Rev. Rom. Med. Vet., 17: 83-92.

40. Gusi, A.M., Bertu, W.J., de Miguel, M.J., Dieste-Pérez, L., Smits, H.L., Ocholi, R.A., Blasco, J.M., Moriyón, I. and Muñoz, P.M. (2019) Comparative performance of lateral flow immunochromatography, iELISA and Rose Bengal tests for the diagnosis of cattle, sheep, goat and swine brucellosis. PLoS Negl. Trop. Dis., 13(6): e0007509.

41. Albukair, A. (2008) Sero-Epidemiological Study on Brucellosis in Sheep and Goats in Al-Ahsa Province, Kingdom of Saudi Arabia. A Thesis Presented in Partial Fulfillment of the Requirements for the Degree of Master of Science (M.Sc.) in Animal Health, Preventive Medicine Department of Clinical Studies College of Veterinary Medicine and Animal Resources, KFU.

42. Mohammed, M.A., Shigidy, M.T. and Al Juboori, A.Y. (2013) Sero-Prevalence and epidemiology of brucellosis in camels, sheep and goats in Abu Dhabi emirate. Int. J. Anim. Vet. $A d v ., 5(2): 82-86$.

43. Abdulmajeed, A. (2015) The Epidemiology of Brucellosis in the Sultanate of Oman. Ph.D. Thesis, Murdoch University, Australia.

44. Nielsen, K. (2002) Diagnosis of brucellosis by serology. Vet. Microbiol., 90(1-4): 447-459.

45. Corbel, M.J. (2006) Brucellosis in Humans and Animals. World Health Organization, Geneva.

46. Nielsen, K., Gall, D., Smith, P., Balsevicius, S., Garrido, F., Ferrer, M.D., Biancifiori, F., Dajer, A., Luna, E., Samartino, L., Bermudez, R., Moreno, F., Renteria, T., Corral, A. (2004) Comparison of serological tests for the detection of ovine and caprine antibody to Brucella melitensis. Rev. Sci. Tech., 23(3): 979-987.

47. Bevins, J.S., Blake, J.E., Adams, L.G., Templeton, J.W., Morton, J.K. and Davis, D.S. (1996) The pathogenicity of Brucella suis biovar 4 for bison. J. Wildlife Dis., 32(4): 581-585.

48. Reviriego, F.J., Moreno, M.A. and Domínguez, L. (2000) Risk factors for brucellosis seroprevalence of sheep and goat flocks in Spain. Prev. Vet. Med., 44(3-4): 167-173.

49. European Commission. (2001) Brucellosis in Sheep and Goats (Brucella melitensis). Scientific Committee on Animal Health and Animal Welfare. European Commission, Brussels, Belgium. p89.

50. Kabagambe, E.K., Elzer, P.H., Geaghan, J.P., OpudaAsibo, J., Scholl, D.T., Miller, J.E. (2001) Risk factors for Brucella seropositivity in goat herds in Eastern and Western Uganda. Prev. Vet. Med., 52(2): 91-108.

51. Al-Majali, A.M. (2005) Seroepidemiology of caprine brucellosis in Jordan. Small Rumin. Res., 58(1): 13-18.

52. Coelho, A.M., Coelho, A.C., Roboredo, M. and Rodrigues, J. (2007) A case-control study of risk factors for brucellosis seropositivity in Portuguese small ruminants herds. Prev. Vet. Med., 82(3-4): 291-301.

53. Rahman, M.S. (2003) Experimental Infection and Protective 
Immunity of Sprague-Dawley Rats with Brucella abortus. Ph.D. Dissertation. Chonbuk National University, Jeonju.

54. Godfroid, J. and Käsborer, A. (2002) Brucellosis in the European Union and Norway at the turn of the twenty-first century. Vet. Microbiol., 90(1-4): 135-145.

55. Fevziye Çetinkaya, Melis Naçar, Tülay Aydın, Nedret Koç, Selma Gökahmetoğlu (2006) Prevalence of brucellosis in the rural area of Kayseri, Central Anatolia, Turkey International Journal of Infectious Diseases, 10(2): 179-181.

56. Avila-Granados, L.M., Garcia-Gonzalez, D.G., ZambranoVaron, J.L. and Arenas-Gamboa, A.M. (2019) Brucellosis in Colombia: Current status and challenges in the control of an endemic disease. Front. Vet. Sci., 6: 321.

57. Zerva, L., Bourantas, K., Mitka, S., Kansouzidou, A. and Legakis, NJ. (2001) Serum is the preferred clinical specimen for diagnosis by PCR. J. Clin. Microbiol., 51: 1661-1664.

58. Kaushik, P., Singh, D.K., Tiwari, A.K. and Kataria, R.S. (2006) Rapid detection of Brucella species in cattle by PCR. J. Appl. Anim. Res., 30: 25-28.

59. Garin-Bastuji, B. and Blasco, J.M. (2004) Caprine and Ovine Brucellosis (excluding B. ovis). Manual of Diagnostic Tests and Vaccines for Terrestrial Animals. $5^{\text {th }}$ ed. OIE. p598-606.

60. Smirnova, E.A., Vasin, A.V., Baev, N.T.S., Klotchenko, S.A., Plotnikova, M.A., Chevryakova, O.V., Sansyzbay, A.R. and
Kiselev, O.I. (2013) Current methods of human and animal brucellosis diagnostics. Adv. Infect. Dis., 3(3): 177-184.

61. Robertson, L., Farrell, D. and P.M. (1977) Highlife: The isolation of Brucella melitensis from contaminated sources. Brucella Vet. J., 133: 193-195.

62. Sayour, A.E. (2004) The Use of Recent Bacteriological Techniques in the Differentiation of Brucella Group of Microorganisms. Ph.D. Thesis, Faculty of Veterinary Medicine, Cairo University.

63. Afifi, M., Abdul-Raouf, U.M., El-Bayoumy, E., Montasser, A.M. and Mohamad, H.A. (2011) Isolation and Bio typing of Brucella melitensis from Upper Egypt. J. Am. Sci., 7(3): 659 .

64. Ibrahim, H.H., Rouby, S., Menshawy, A. and Ghazy, N. (2016) Seroprevalence of camel brucellosis and molecular characterization of Brucella melitensis recovered from dromedary camels in Egypt. Res. J. Vet. Pract., 4(1): 14-17.

65. Hasani, S.M., Mirnejad, R., Amani, J. and Vafadar, M.J. (2016) Comparing rapid and specific detection of Brucella in clinical samples by PCR-ELISA and multiplex-PCR method Iran. J. Pathol., 11(2): 144-150.

66. Kaaboub, E.A., Ouchene, N., Ouchene-Khelifi, N.A. and Khelef, D. (2019) Serological and histopathological investigation of brucellosis in cattle in Medea region, Northern Algeria. Vet. World, 12(5): 713-718. 